Uluslararası Mühendislik

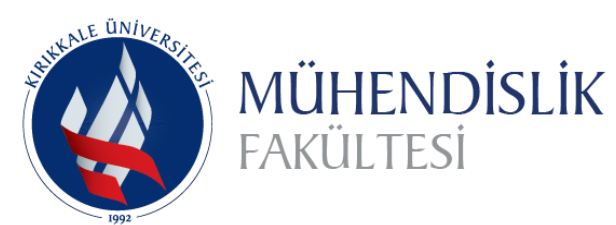

Araştırma ve Geliştirme Dergisi UMAGD, (2022) 14(1), 228-236.

International Journal of

Engineering Research and

Development

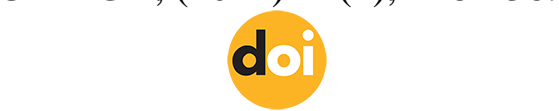

Cilt/Volume:14 Sayı/Issue:1 Ocak/January 2022

Araştırma Makalesi / Research Article

\title{
Investigating the Microstructural Properties and Phase Distributions of TIG Welded AISI/SAE 304L Stainless Steel Runners Used in TNT Filling of Ammunitions
}

\author{
Oğuz Akgü̈l ${ }^{1}$, Aziz Barış Başyiğit ${ }^{2 *}$ iD \\ ${ }^{1}$ Kirlkkale University, Institute of Science, Department of Defense Technologies, 71450, Kırlkkale, TURKEY \\ ${ }^{2 *}$ Kırıkkale University, Faculty of Engineering, Department of Metallurgical and Material Engineering, 71450, Kirıkkale, TURKEY
}

Başvuru/Received: $26 / 10 / 2021$

Kabul / Accepted: 15/11/2021

Çevrimiçi Basım / Published Online: 31/01/2022

Son Versiyon/Final Version: 31/01/2022

\begin{abstract}
Among the stainless steels, the most widely used group is austenitic stainless steels. The prominent reason why austenitic stainless steels are preferred in welded stainless steel fabrications is their good weldability. AISI/SAE 304L austenitic stainless steels exhibit adequate corrosion resistance in oxidizing environments. AISI/SAE 304L austenitic stainless steels are also used in filling interfaces of runners between the Tri-Nitro-Toluen filling vessel and ammunitions in defense industry. For the manufacture of the runners, the stainless steel plates and the stainless steel pipes are mainly joined by fusion welding. These runners are cleaned with hot tapping water at $70^{\circ} \mathrm{C}$ after each filling of ammunitions by TNT so that cleaning operation can deteriorate the corrosion properties of runners especially weld zones. Austenitic stainless steel weldments include basically delta-ferrite and austenite phases on weld regions. Delta ferrite phase exhibits resistance to chloride bearing medias while austenite phase is more resistive to high temperature oxidizing ambients

In this study; $3 \mathrm{~mm}$ thick 304L austenitic stainless steel plates and rings are welded to each other with two different filler weld wires of ER316L and ER2209 by Tungsten Inert Gas welding method under pure argon shielding gas. Weld metals and heataffected zones of welded joints were examined using optical metallurgical microscope. It has been determined that the additional filler weld wires have changed the weld metal and the heat affected zone microstructures and phase distributions dominantly. Microstructures of all welded joints have been compared. Besides, phase distributions of weld metals and heat effected zones are made by image analysis software and Schaefflers diagram. ER2209 welding filler metal increased the phase fraction of delta-ferrite in weld metals while it decreased the austenite phase fraction as compared to ER316L filler metal.
\end{abstract}

Key Words

"304L stainless steels, TIG welding, Phase analysis, Phase distribution, Schaeffler diagram"

*Sorumlu Yazar: $\underline{\text { abbasyigit@kku.edu.tr }}$ 


\section{Introduction}

Stainless steels are a family of iron base alloys having excellent resistance to corrosion. Because of high corrosion resistance, stainless steel sheets are progressively used for kitchen, transportation, building constructions, etc (William et.al. 2014).

The largest group of stainless steels are the austenitic alloys that cannot be transformation hardened. Non-magnetizable austenitic steels; since they retain their austenitic microstructure at both room temperature and elevated temperatures, they cannot be subjected to normalizing and hardening heat treatment. They can only be strenghened by cold working within the limits (Pollard, 1993).

Weldability is one of the required properties of engineering materials (Joseph et.al. 2015 and Talabi et.al. 2014). One of the most important reasons why austenitic stainless steels are preferred in welded stainless steel fabrications is that these types of steels have good weldability properties (Tülbentçi, 1985). Austenitic stainless steels includes dominantly austenite and minor amounts of deltaferrite phase. Delta-ferrite phase exhibits resistance to basically chloride including medias while austenite phase is more effective in general atmospheric corrosion and elevated temperature corrosion. Welding of these alloys results in weld metal having basically deltaferrite and/or austenite phases majorly according to the types of filler metals that used (Lippold and Kotecki, 2005). As the total mechanical values of delta-ferrite and austenite phases are quite different so it also plays an important role in selection of the filler metal for determining the mechanical properties of these stainless steels weldments (Gunn, 2003).

The runners are used to increase the production speed and product quality during the liquid TNT filling of ammunitions (Margolin M. and Skettini E., 1958). The runners are in contact with pressurized water at high temperature in order to prevent the TNT, which is in the sensitive explosive class, from easily igniting and exploding. For this reason, all runners are constantly exposed to a corrosive environment. Stainless steels with high corrosion resistance are used in such corrosive environments. Austenitic steels are one of the best choices, as they exhibit good mechanical properties and corrosion performance (Gülenç et.al. 2005). Austenitic stainless steel is the most corrosion resistant and because of that reason it has lots of applications in chemical plants. The austenitic steels generally have low yield strength and high ultimate tensile strength that is why they are often very ductile. They have excellent properties at cryogenic temperature and have higher strengths at $540^{\circ} \mathrm{C}$ than the 400 series. The microstructures of these steels are either all austenite, or ferrite in a matrix of austenite (Gadewar et.al. 2010). AISI (American Iron And Steel Institute)/SAE (Society of Automotive Engineers) 304L austenitic stainless steel was selected for all these reasons.

Until the end of the 19th century, forge welding was the only welding process the blacksmith had used years together, to join iron and steel by heating and hammering. Arc welding, oxy fuel welding and electric resistance welding processes followed soon after. Due to technology advance, several modern techniques were developed by welding engineers, such as semi automatic and automatic processes, gas metal arc welding, submerged arc welding, and electro slag welding. Among them one of the proper joining technique is gas tungsten arc welding (TIG) (Patel A. and Patel S., 2014). TIG welding method is selected in this research. ER316L TIG welding rod is preferentially used for austenitic stainless steels and ER2209 TIG welding rod is also used for duplex (ferritic-austenitic) stainless steels according to ISO 14343-A and AWS A 5.9 standards. But the effects of both of the two ER316L and ER2209 filler metals on microstructural and phase differences mainly as delta-ferrite and austenite is studied in this work.

In this study, two different filler materials (ER316L and ER2209) are used to investigate for welding AISI/SAE 304L austenitic stainless steel sheets and rings. As austenite phase exhibits corrosion resistance to high temperature oxidizing medias while delta-ferrite phase resists against chloride bearing ambients, so that one can decide whether the dominant phase should be preferred as austenitic or delta ferritic on weldments (Lippold and Kotecki, 2005). Microstructural developments and phase analysis of welded joints are throughly investigated.

\section{Experimental Methods}

Four samples of $3 \mathrm{~mm}$ thick 304L austenitic stainless steel sheets and rings are joined to each other, using TIG welding method.

Optical emission spectral analysis results of raw 304L stainless steel alloy by Amatex Spectromax brand spectrometer are given in Table 1. Experimental materials are consistent with the standard documents (ASM Handbook Vol. 2, 2005; ASTM A240, 2017).

Table 1. Chemical compositions of materials used in this study

\begin{tabular}{cccccccccccccccc}
\hline \multicolumn{10}{c}{ Elements $(\%$ Weight $)$} \\
\hline Material & $\mathbf{C}$ & $\mathbf{S i}$ & $\mathbf{M n}$ & $\mathbf{P}$ & $\mathbf{S}$ & $\mathbf{C r}$ & $\mathbf{M o}$ & $\mathbf{N i}$ & $\mathbf{C u}$ & $\mathbf{N}$ & $\mathbf{F e}$ & $\mathbf{O t h e r s}$ \\
\hline $\begin{array}{c}\text { 304L } \\
\text { (sheet) }\end{array}$ & 0.0180 & 0.376 & 1.83 & 0.020 & $0.0005<$ & 18.58 & 0.210 & 7.93 & 0.336 & 0.073 & 70.4 & 0.226 \\
$\begin{array}{c}\text { 304L } \\
\text { (ring) }\end{array}$ & 0.0130 & 0.357 & 1.24 & 0.022 & 0.026 & 18.46 & 0.237 & 7.99 & 0.553 & 0.062 & 70.8 & 0.240 \\
\hline
\end{tabular}


TIG welding is applied by two passes with direct current (-) under pure argon shielding gas. Chemical compositions of ER316L and ER2209 TIG welding rods are given in Table 2 that provided from manufacturer.

Table 2. Chemical compositions of TIG welding rods provided by manufacturers data

\begin{tabular}{|c|c|c|c|c|c|c|c|}
\hline \multirow{2}{*}{$\begin{array}{l}\text { EN ISO 14343- } \\
\text { A, AWS A5.9 } \\
\text { TIG Rods } \\
\text { (ISO14343,2017; } \\
\text { AWS A.5.9, } \\
\text { 2017) }\end{array}$} & \multicolumn{7}{|c|}{ Elements (\% Weight) } \\
\hline & $\mathbf{C}$ & Mn & $\mathbf{S i}$ & $\mathbf{N i}$ & $\mathrm{Cr}$ & Mo & $\mathbf{N}$ \\
\hline ER316L & $0.025<$ & 1.7 & 0.3 & 12 & 19 & 2.8 & -- \\
\hline ER2209 & $0.01<$ & 1.5 & 0.5 & 8.5 & 22.75 & 3.2 & 0.17 \\
\hline
\end{tabular}

Test samples are prepared as given in Figure 1.

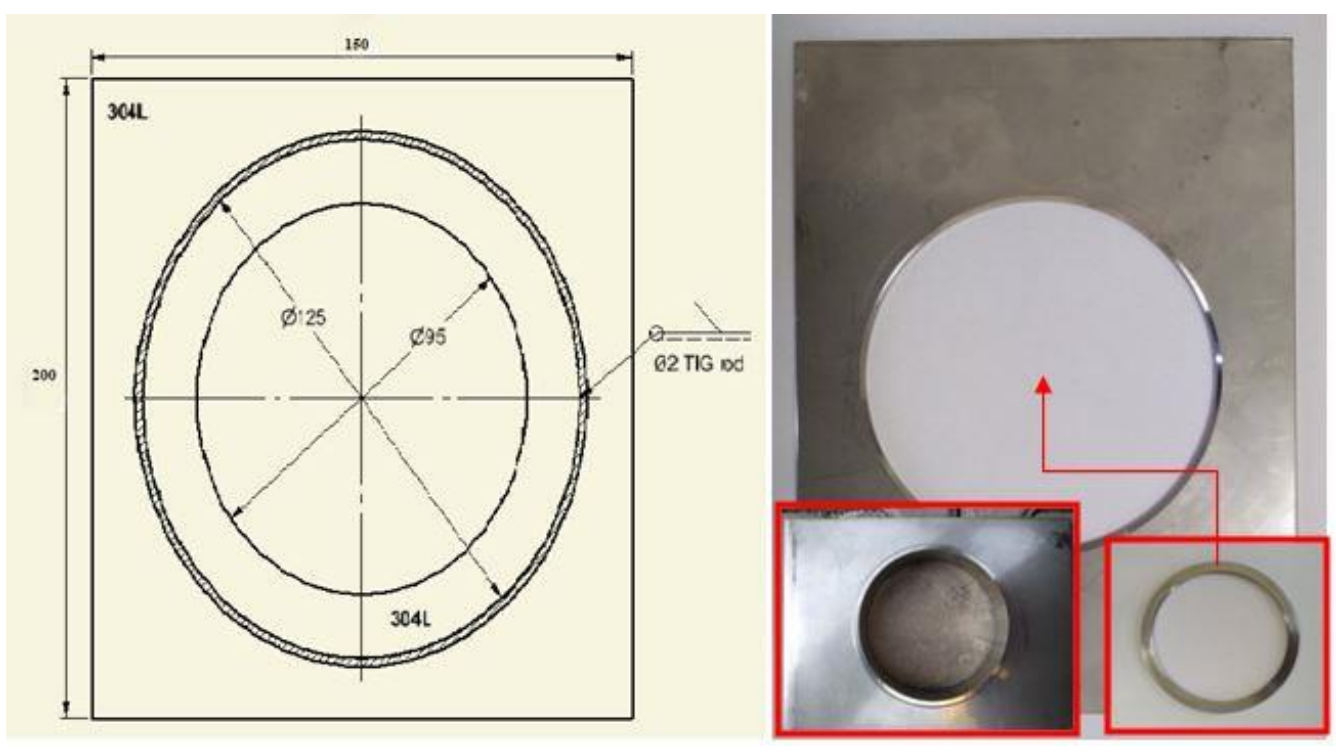

(a)

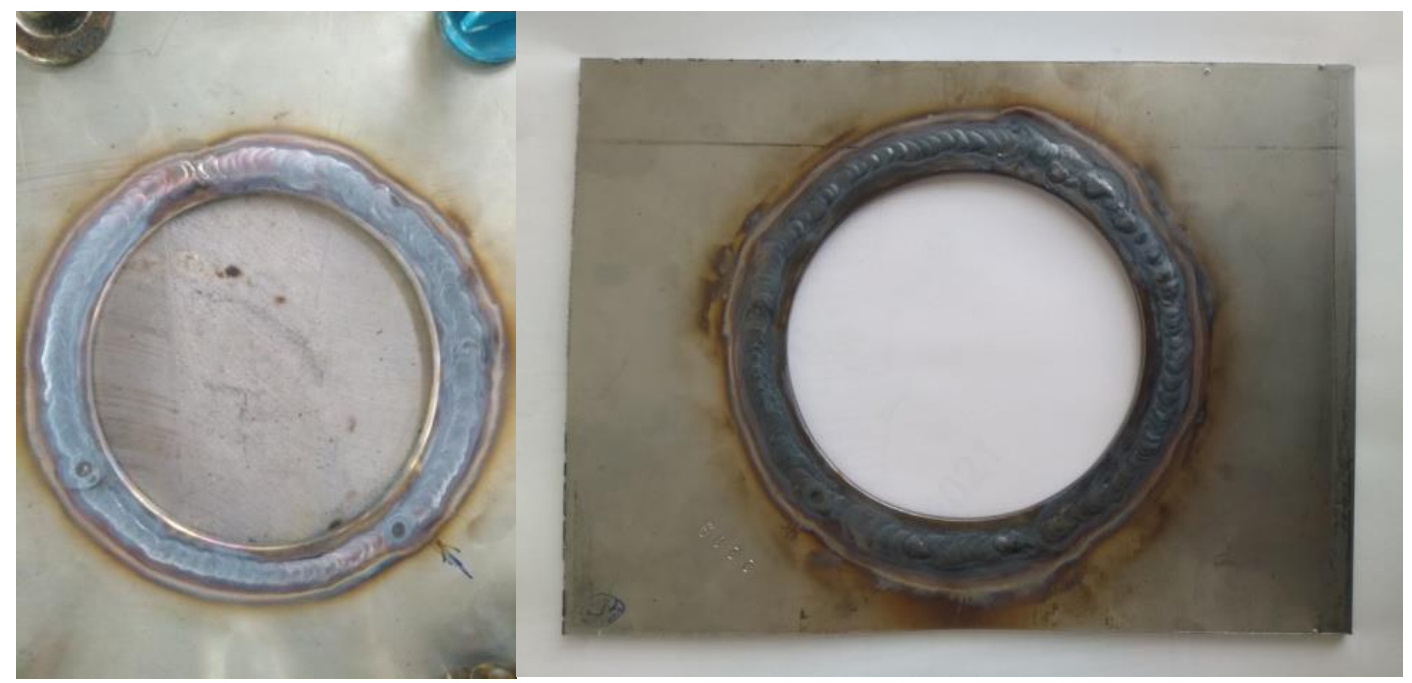

(b)

Figure 1. Layout diagram and Figures of test specimens (a) before and (b) after (both sides) welding operation 
WT20 2\% thoriated welding electrode is used in joining operations.

TIG welding operation parameters are given in Table 3.

Table 3. TIG welding parameters

\begin{tabular}{|c|c|c|c|c|c|c|c|c|c|c|c|}
\hline \multirow{2}{*}{$\begin{array}{c}\text { ISO 14343, } \\
\text { AWS A5.9 } \\
\text { TIG Rods } \\
\text { Ø2 mm }\end{array}$} & \multicolumn{2}{|c|}{$\begin{array}{c}\text { Current } \\
\text { DC(-) } \\
\text { (Amperes) }\end{array}$} & \multicolumn{2}{|c|}{$\begin{array}{c}\text { Welding } \\
\text { Voltage } \\
\text { (Volts) }\end{array}$} & \multicolumn{2}{|c|}{$\begin{array}{l}\text { Shielding Gas } \\
\text { Flow (lt/min) }\end{array}$} & \multicolumn{2}{|c|}{$\begin{array}{c}\text { Welding Speed } \\
(\mathbf{m m} / \mathbf{s n})\end{array}$} & \multicolumn{2}{|c|}{$\begin{array}{c}\text { Welding Heat } \\
\text { Input } \\
\text { (Joule/mm) }\end{array}$} & \multirow[t]{2}{*}{$\begin{array}{l}\text { Tungsten } \\
\text { Electrode }\end{array}$} \\
\hline & $\begin{array}{l}\text { Root } \\
\text { Pass }\end{array}$ & $\begin{array}{l}2^{\text {nd }} \\
\text { Pass }\end{array}$ & $\begin{array}{l}\text { Root } \\
\text { Pass }\end{array}$ & $\begin{array}{l}2^{\text {nd }} \\
\text { Pass }\end{array}$ & $\begin{array}{l}\text { Root } \\
\text { Pass }\end{array}$ & $\begin{array}{l}2^{\text {nd }} \\
\text { Pass }\end{array}$ & $\begin{array}{l}\text { Root } \\
\text { Pass }\end{array}$ & $\begin{array}{l}2^{\text {nd }} \\
\text { Pass }\end{array}$ & $\begin{array}{l}\text { Root } \\
\text { Pass }\end{array}$ & $\begin{array}{l}2^{\text {nd }} \\
\text { Pass }\end{array}$ & \\
\hline ER316L & 110 & 105 & 11 & 10 & 12 & 10 & 1,81 & 2,03 & 467.96 & 362.07 & $\begin{array}{l}\text { (Red- \%2 } \\
\text { Thoirated) }\end{array}$ \\
\hline ER2209 & 110 & 105 & 11 & 10 & 12 & 10 & 1,82 & 2,11 & 465.38 & 348.34 & \\
\hline
\end{tabular}

In order to examine the microstructural changes of the samples joined with two different TIG welding rods, a microstructure examination specimen has been prepared for each condition. In order to facilitate the grinding and polishing process, the specimens have been molded in bakelite.

After the grinding and polishing processes, the microstructure examination samples were etched in $20 \%$ concentrated sodium hydroxide $(\mathrm{NaOH})$ etching solution at 2.5 volts and 0.3 amperes of current for 15 seconds with the electrolytic etching method. The microstructures have been investigated by a 'LEICA DM 4000M' brand metallurgical microscope.

The 'Kameram' licensed software is used for phase analysis estimations in laboratory according to ASTM E1245 and ASTM E562 standards. In addition, phase distributions of weld metals on each samples are also investigated by Schaeffler's diagram.

\section{Results and Discussion}

\subsection{Microstructural examination of the specimens welded by ER316L TIG rod}

Microstructural examinations and phase analysis result screens of heat affected zones are shown in Figure 2-(a) and (b) respectively. The dominant phase (lighter colour) in microstructure indicates austenite, and the dark lines indicate the grains of delta-ferrite. According to the phase analysis the delta-ferrite ratio is approximately $21 \%$ and the austenite ratio is $77 \%$. As the rolled phase structure on the 304L base material side (right side of the image) approaches HAZ, its linearity disrupts and develops into a partially slightly dendritic structure.
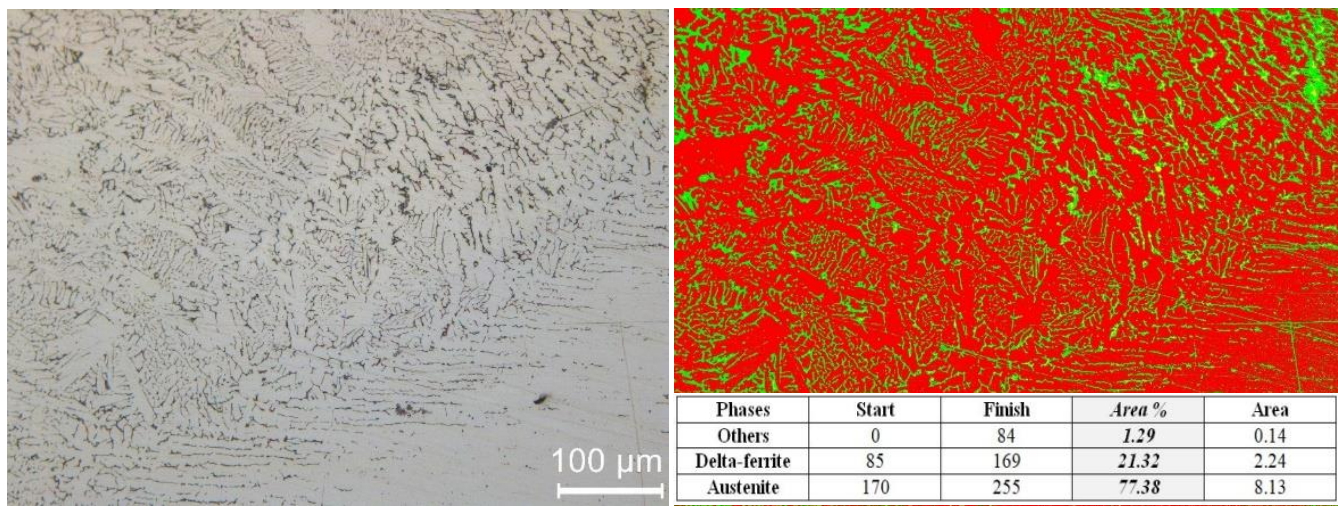

Figure 2. (a) micrograph and (b) phase analysis of HAZ region of the specimens welded by ER316L TIG rod

Microstructural examinations and phase analysis result screens of weld metal are shown in Figure 3-(a) and (b). The lighter regions indicate austenite, and the dark lines indicate delta-ferrite grains. The delta-ferrite ratio is approximately $6.4 \%$ and the austenite ratio is $93.6 \%$ according to the image analysis by volume. 


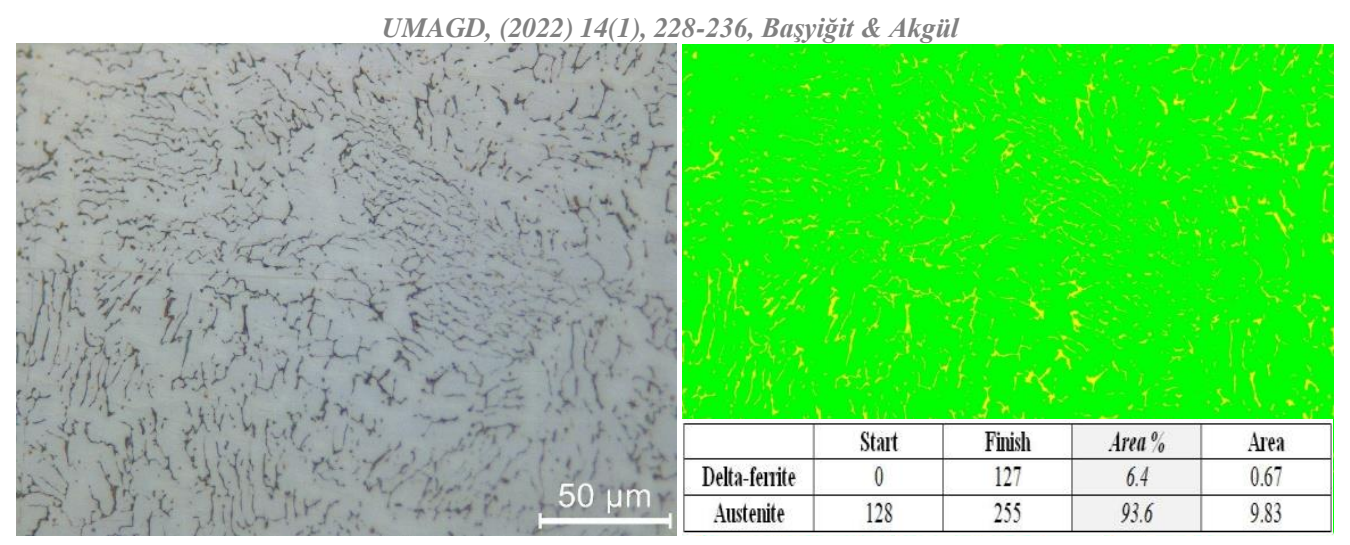

Figure 3. (a) micrograph and (b) phase analysis of weld metal region of the specimens welded by ER316L TIG rod

\subsection{Microstructural examination of the specimens welded by ER2209 TIG rod}

Microstructural examinations and phase analysis result screens of HAZ are given in Figure 4-(a) and (b) respectively. The austenite ratio is approximately $42 \%$ and the delta-ferrite ratio is approximately $55 \%$ according to the phase analysis. As the rolled phase structure on the 304L base material side (left side of the image) approaches HAZ linearly and develops into a dendritic structure.
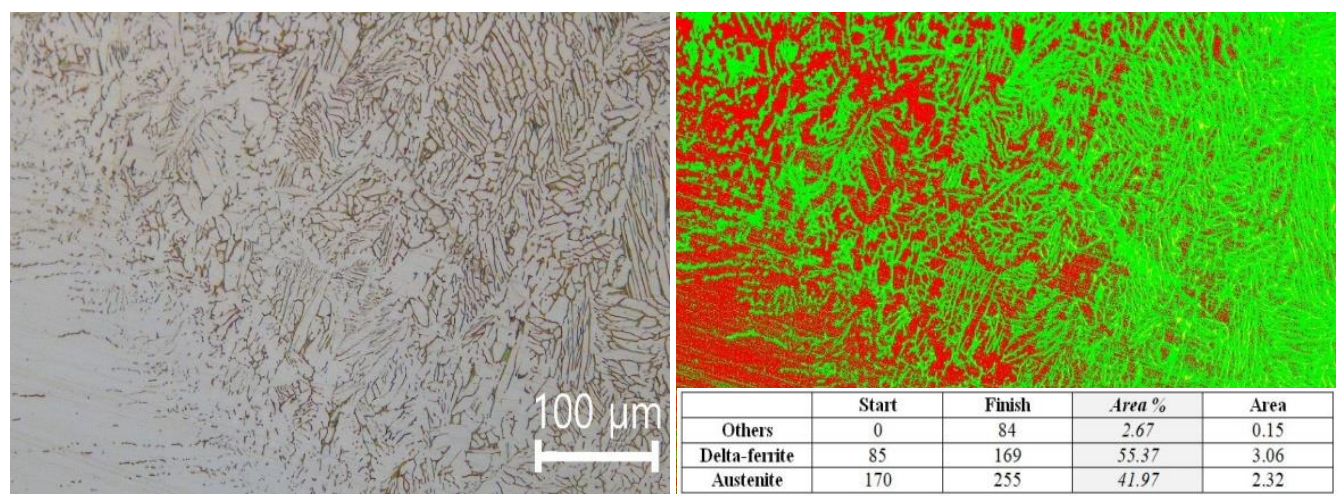

Figure 4. (a) micrograph and (b) phase analysis of HAZ region of the specimens welded by ER2209 TIG rod Microstructural examinations and phase analysis result screens of weld metal are shown in Figure 5-(a) and (b) respectively.
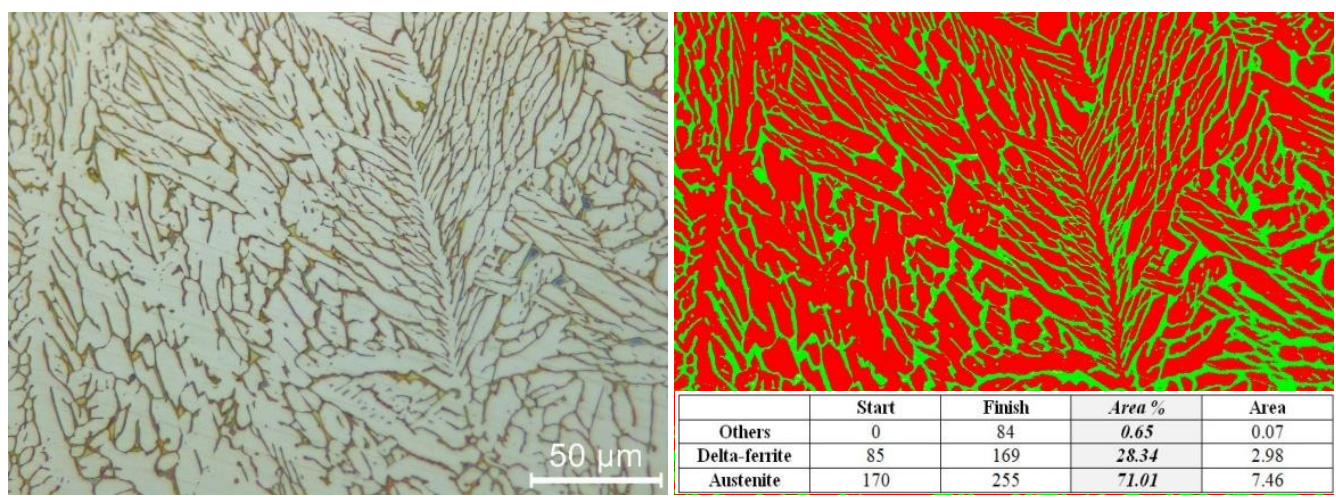

Figure 5. (a) micrograph and (b) phase analysis of weld metal region of the specimens welded by ER2209 TIG rod

The weld metal structure is given in dendritic austenite according to the Figure 5-(a). It has been determined that the main structure consists of approximately $28 \%$ delta-ferrite and $71 \%$ austenite in the micro-structural phase analyzes in Figure 5-(b).

\subsection{Phase Estimation by Schaeffler Diagram}

Anton Schaeffler-1949 diagram basically focuses on equations estimating chromium and nickel equivalents (Cr. eq, Ni. eq.) by weights in percentage. Schaeffler's chromium and nickel equivalents by weight for base and weld metals and 2 different TIG rods in percentages are estimated according to Equations 1 and 2 below (Lippold \& Kotecki, 2005). 
Schaefflers' Chromium Equivalent;

$C r_{E q}=C r \%+M o \%+1,5 \cdot S i \%+0,5 \cdot N b \%$

Schaefflers' Nickel Equivalent;

$N i_{E q}=N i \%+30 . C \%+0,5 \cdot M n \%$

The equivalent values for $304 \mathrm{~L}$ sheet metal;

$\mathrm{Cr}_{E q, 304 L-S}=19.41$

$N i_{E q, 304 L-S}=9.38$

The equivalent values for $304 \mathrm{~L}$ ring metal;

$C r_{E q, 304 L-R}=19.16$

$N i_{E q, 304 L-R}=8.96$

The equivalent values for ER316L TIG Welding Rod;

$\mathrm{Cr}_{E q, E R 316 L}=22.25$

$N i_{E q, E R 316 L}=13.57$

The equivalent values for ER2209 TIG Welding Rod;

$C r_{E q, E R 2209}=26.70$

$N i_{E q, E R 2209}=9.52$

Base metals of 304L (both ring and sheet) include approximately 82\% austenite and remaining delta-ferrite according to Schaeffler's estimations and besides $97 \%$ austenite with remaining delta-ferrite according to image (micro-structural) phase analysis.

Although ER316L TIG welding rod contains 12\% delta-ferrite, the weld metal of sample joined by ER316L TIG rod contains approximately 14\% delta-ferrite and remaining austenite as seen in Figure 6.

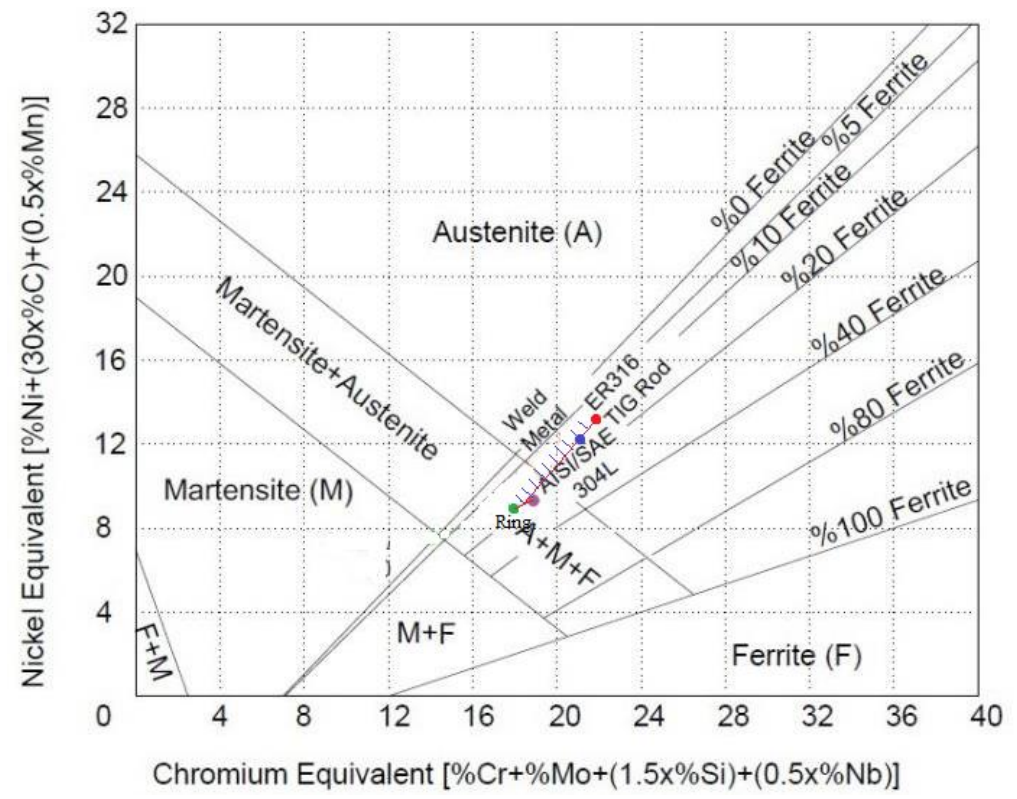

Figure 6. Phase locations of sample joined by ER316L TIG Rod plotted on Schaeffler's Diagram (Brando et.al. 1992)

ER2209 TIG welding rod contains approximately $70 \%$ delta-ferrite and remaining austenite by volume according to Figure 7 . Weld metal of sample joined by ER2209 TIG rod includes approximately 55\% delta-ferrite and remaining austenite. 


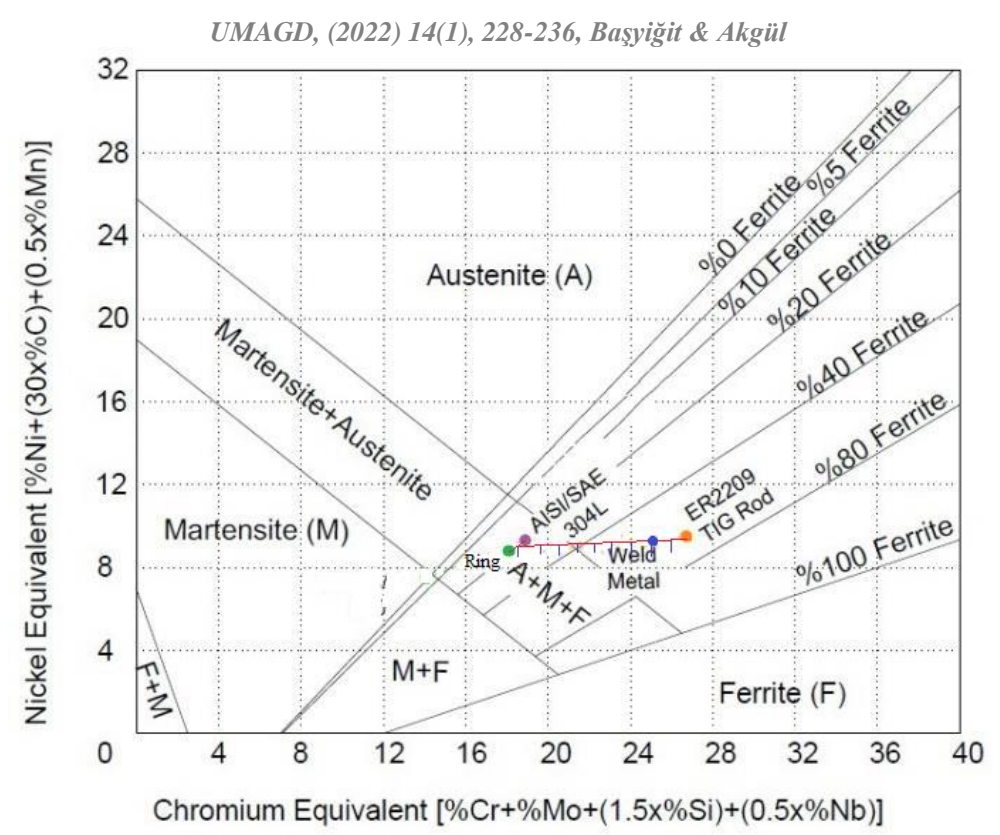

Figure 7. Phase locations of sample joined by ER2209 TIG Rod plotted on Schaeffler's Diagram (Brando et.al. 1992) Results of phase (image) analysis and Schaeffler's estimations are listed in Table 4.

Table 4. Results of Phase Analyzing Results

\begin{tabular}{ccccccc}
\hline \multirow{2}{*}{$\begin{array}{c}\text { Analyzing } \\
\text { Method }\end{array}$} & $\begin{array}{c}\text { Phases } \\
\text { Ratios (by } \\
\text { volume) } \%\end{array}$ & $\begin{array}{c}\text { 304L } \\
\text { unwelded } \\
\text { Base metals }\end{array}$ & $\begin{array}{c}\text { ER316L TIG } \\
\text { Rod }\end{array}$ & $\begin{array}{c}\text { ER2209 TIG } \\
\text { Rod }\end{array}$ & $\begin{array}{c}\text { Joined by } \\
\text { ER316L } \\
\text { TIG Rod }\end{array}$ & $\begin{array}{c}\text { Joined by } \\
\text { ER2209 } \\
\text { TIG Rod }\end{array}$ \\
\hline & Delta-ferrite & 3 & Not applicable & Not applicable & $\mathbf{6 . 4}$ & $\mathbf{2 8 . 3 4}$ \\
$\begin{array}{c}\text { Image (phase) } \\
\text { Analysis }\end{array}$ & Austenite & 97 & Not applicable & Not applicable & $\mathbf{9 3 . 6}$ & $\mathbf{7 1 . 0 1}$ \\
& $\begin{array}{c}\text { The other } \\
\text { minor phases }\end{array}$ & 0 & Not applicable & Not applicable & $\mathbf{0}$ & $\mathbf{0 . 6 5}$ \\
$\begin{array}{c}\text { Schaefflers } \\
\text { Estimation }\end{array}$ & Delta-ferrite & 18 & 12 & 70 & $\mathbf{1 4}$ & $\mathbf{5 5}$ \\
\hline
\end{tabular}

Comparison of the amounts of delta-ferrite and austenite phases obtained from image analysis and Schaefflers equations in $\%$ volume on weld metal is given in Figure 8.

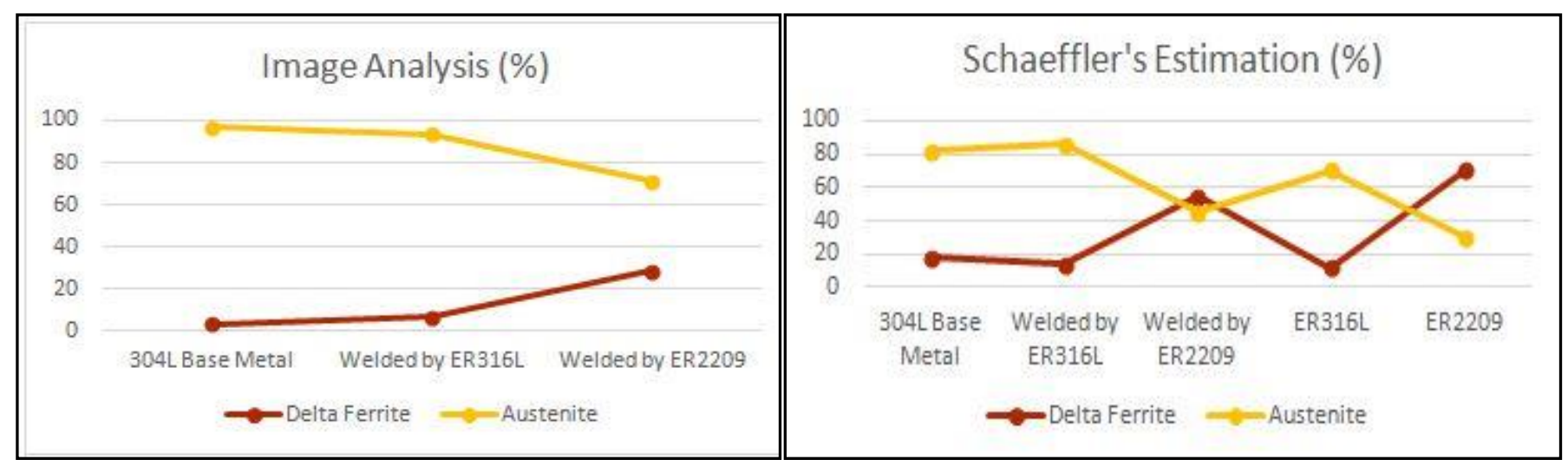

Figure 8. Comparison of the amounts of delta-ferrite and austenite phases 
Image analysis results are not quite far from Schaeffler's estimations; however there are some amounts of differences in both of the results that given in Table 4. As chromium is a delta-ferrite stabilizing element so that increasing amounts of chromium element in TIG welding rod also increases the delta-ferrite amounts in weld metals (Lippold and Kotecki, 2005).

ER2209 TIG welding rod has more amounts of chromium element as compared to ER316L so that the delta-ferrite ratios are also determined to be greater than ER316L TIG rod in amounts by volume both seen from image analysis and Schaeffler's estimation results indicated in Table 4 and Figure 8.

\section{Conclusions}

ER316L TIG welding rod is generally preferred for austenitic stainless steels while ER2209 TIG welding rod is preferred for duplex (ferritic-austenitic) stainless steels according to ISO 14343-A and AWS A 5.9 standards. In this context, such a study was worked out to see the effects and differences on microstructures between two different filler metals. The aim of the study is to examine the effects of different welding rods on microstructure and phase distributions. The following findings were identified in this study.

1. It has been determined that the type of TIG welding rod has a domestic effect on micro-structure form of weld metal zones.

2. When the microstructure of the weld metal of samples joined with ER2209 TIG welding rod is examined, it has been seen that the structure is in the form of branched dendritic austenite. ER2209 filler metal decreased the austenite ratios to $71 \%$ by volume as compared to unwelded base metal 304L having $97 \%$ of austenite in consequence of filler metal having more amounts of chromium element as a ferrite stabilising effect on weld metal.

3. Predominant austenite and delta-ferrite phases are seen in microstructure of the weld metal center and the heat-affected zones of the welded samples joined with ER316L TIG welding rod. ER316L TIG rod preserved the austenite phase ratios to approximately $94 \%$ by volume as compared to base metal 304L having $97 \%$ of austenite ratio by volume.

4. When the microstructure of the heat-affected zone of samples joined with ER2209 TIG welding rod is examined, it has been observed that the structure is composed of approximately equidistant austenite and delta-ferrite while partial dendritic structure is observed in HAZ of samples joined by ER316L TIG rod.

5. Increasing amounts of chromium element in TIG welding rod also increased the delta-ferrite phase ratios in welded samples according to the phase (image) analysis and Schaeffler's estimations as chromium is a ferrite stabilizing element.

6. Phase (micro-structural image) analysis and Schaeffler's estimations are concluded in close values between each other owing stable results.

7. As a result, considering the distribution of phases in weld metal and HAZ regions of samples in case of needs for higher amounts of delta-ferrite instead of austenite in consequence of various corrosion and mechanical property demands, it would be more appropriate to use ER2209 TIG welding rod instead of ER316L filler metal for the welded equipments in TNT filling opearations of defense industries.

\section{Acknowledgements}

Authors express their thanks especially to Mehmet KALKAN and MKE Weapon Factory staff for precious test supports.

\section{References}

Brando W. S., Buchno V. T. L., Marques P. V., Modenesi P. J., Avoiding Problems When Welding AISI 430 Ferritic Stainless Steel, Welding International, 6 (9), pp. 713-716, 1992.

Classification of Welding consumables ISO14343, 2017.

Classification of Welding consumables AWS A.5.9, 2017.

Gadewar S., Swaminadhan P., Harkare M., Experimental Investigations of Weld Characteristics for a Single Pass TIG Welding with Stainless Steel, Journal of Engineering and Technology, 2(8), pp. 3676-3686, 2010.

Gunn R.N., Duplex stainless steels microstructure properties and applications, Abington Publishing, p.58, 2003.

Gülenç B., Develi K., Kahraman N., Durgutlu A., Experimental Study of the Effect of Hydrogen in Argon as a Shielding Gas in MIG Welding of Austenitic Stainless Steel, International Journal of Hydrogen Energy, 30(13), pp. 1475-1481, 2005.

Joseph O.O., Leramo R.O., Ojudun O.S., Journal of Materials and Environmental Science 6-1, p. 101, 2015.

Lippold J.C., Kotecki D., Welding Metallurgy and Weldability of Stainless Steels, Wiley Interscience, pp. 56-57, 2005.

Margolin M., Skettini E., Ammunition Loading Techniques, Explosive Development Section Feltman Research and Engineering 
Laboratories, p. 2, 1958.

Patel A., Patel S., The Effect of Activating Flux in Tig Welding, International Journal of Computational Engineering Research 4(1) pp. 65-70, 2014.

Pollard B., Welding brazing and soldering, ASM Metals Handbook, V.6, pp. 482-493, 1993.

Properties and Selection; Non-Ferrous Alloys and Special Purpose Materials, ASM International, ASM Handbook Volume 2, pp. 618-627, 2005.

Standard Specification for Welding, Brazing, and Fusing Qualifications, ASME BPVC Section IX, 2015.

Standard Test Method for Determining Volume Fraction by Systematic Manual Point Count; ASM International: Almere, The Netherlands, ASTM E562-11, 2011.

Standard Practice for Determining the Inclusion or Second Phase Constituent Content of Metals by Automatic Image Analysis; ASM International: Almere, The Netherlands, ASTM E1245, 2008.

Standard Specification for Chromium and Chromium-Nickel Stainless Steel Plate, Sheet, and Strip for Pressure Vessels and for General Applications, ASTM A240, 2017.

Talabi S.I., Owolabi O.B., Adebisi J.A., Yahaya T., Advanced Reservoir and Production Engineering Manual 9-4, p. 181, 2014.

Tülbentçi K., Paslanmaz Çeliklerin Kaynağı, Böhler Kaynak Dünyası, pp. 5-10, 1985.

William D. Callister J. , Rethwisch D. G., Materials Science and Engineering: An Introduction, John Wiley \& Sons Inc., pp. 57-58, 2014. 